\title{
FACTORS THAT DETERMINE THE PERFORMANCE IMPROVEMENT OF SMALL AND MEDIUM ENTERPRISES IN JAKARTA
}

\author{
Rudy Santosa Sudirga \\ Department Management, University Bunda Mulia, Jakarta, Indonesia
}

\begin{abstract}
The research of factors that determine the performance improvement of small and medium enterprises in Jakarta is based on the background of increasing small and medium enterprises sector in Jakarta. The benefits of this study are to find out what factors are most influential on the performance of small and medium enterprises in Jakarta. The authors took a number of 200 samples of small and medium enterprises in Jakarta, and the research data analysis technique is multiple regression with Structural Equation Modelling IBM SPSS Amos version 23. The results of respondents who answered the questions were dominated by respondents with a high school education background 152 people (76\%), with ages ranging between 41-50 years 117 people (58.5\%), and having income turnover above 90 million rupiah per month 122 people (61\%), so it can be categorized that the majority of small and medium business entrepreneurs are educated in high school and are still in the productive age range. The results showed that the Business/Product Innovation, Business Competence, Business Capital, and Population had a significant effect on Business Performance, while variables Environmental Factors have no significant effect on Business Performance.
\end{abstract}

Keywords: improvement, business performance, small and medium enterprises

\section{INTRODUCTION}

The background of this research is the increase of small and medium enterprises and competition in the small and medium business sector in Jakarta. The increase in small and medium enterprises has certainly had a good impact on improving the economy in Indonesia. In order for small and medium enterprises in Jakarta to continue to improve and develop well, and with the rapid development of small and medium enterprises in Jakarta, with such rapid growth, many small and medium enterprises are closed or have stopped their businesses, therefore the author wants to know and intends to analyse and evaluate the factors that determine the performance improvement of

*Corresponding Author.

e-mail: rudysudirga@yahoo.com

https://doi.org/10.37715/jee.v8i2.1123 small and medium enterprises in Jakarta and their contribution to economic growth in Jakarta.

According to (Keller, 2013), innovation is a change in taste in competition with other companies. Companies that want to maintain their leadership position must continually innovate. Whereas according to (Najib, 2011), innovation factors are very positively needed in improving and developing small and medium businesses in Indonesia.

According to (Mc Daniel \& Gitman, 2015), capital is very important in supporting business activities such as forecasting sales, expenditures and operating costs of the company, including cash budget, capital budget, and operating budget. Meanwhile, according to (Abe, 2015), capital investment is needed to support small and 
Rudy Santosa Sudirga / Factors that Determine the Performance Improvement of Small and Medium Enterprises in Jakarta / JEE, Vol. 7, No. 2, September 2019, pp 73-80

medium enterprises in the Asia Pacific, to be able to develop, increase and progress well.

According to (Mc Daniel \& Gitman, 2015), the environment also influences changes in the company, because the company regularly collects and evaluates information about external conditions with the aim of identifying market opportunities in the future. Whereas according to (Guillermo \& Gaston, 2013), environmental factors are very influential for the expansion of small and medium businesses internationally. Whereas (Anggadwita et al., 2017), also mention that the socio-cultural environment has an effect and influence in small and medium business activities and contributes to the growth of economic activities of small and medium enterprises in developing countries.

According to (Griffin \& Pustay, 2015), the population of a country, especially developing countries, contributes to economic growth. In this case, it can also be interpreted to affect the development of small and medium enterprises in developing countries. Whereas according to (Budiman, 2016) and according to (Wahyuni $\& \mathrm{Ng}$, K.K., 2012), the competitive performance of a small and medium business is also determined by the size of the population in that country, because a country's per capita income and gross domestic product (GDP) play a role in determining the performance of the growth of a country's small-scale business enterprise.

According to (Musthofa, 2017), business competencies, product innovation, and business performance influence or affect a business in Indonesia, especially small and medium businesses.

Business competencies have operational variable indicators including:

- Can identify business opportunities

- Can think and act creatively

- Can manage business risk
While product innovation has operational variable indicators including:

- New products on the market

- Offering new ideas on the market

- Creative design

- Offering and presenting new advantages in the market

- Products can provide solutions to problems faced creatively

- Can present new features on the market.

While business performance has operational variable indicators including:

- Customer growth

- Business growth

- Profit or profit growth.

From the entire library and international journals' explanations, a summary of the factors that influence or affect the business performance of small and medium enterprises are as follows:

- Business innovation or product innovation

- Business competency

- Business performance

- Venture capital

- Population of a community or population of a country

- Environmental factor

A summary of the factors that influence or affect the business performance of small and medium enterprises are as follows: business innovation or product innovation, business competency, business performance, venture capital, population of a community or population of a country, and environmental factor.

Hypothesis testing: the author intends to analyse and evaluate the factors (business innovation or product innovation, business competency, business performance, venture capital, 
population of a community or population of a country, environmental factor) that determine or influence the performance improvement of small and medium enterprises in Jakarta. In other words whether variables product innovation, business competency, capital, population of a community, and environmental factor affect the business performance of small and medium enterprises in Jakarta.
This study aims to determine the growth and development of small and medium enterprises, and what factors are most influential on the performance of small and medium enterprises in Jakarta.

In addition, in the long run it is also very beneficial for small and medium businesses in Jakarta, to find out what factors determine the

Table 1 Research Road Map

\begin{tabular}{|c|c|c|c|c|c|c|}
\hline \multirow[b]{2}{*}{ Research Title } & $\mathrm{Y}$ & $\mathrm{Y}$ & $\mathrm{Y}$ & $\mathrm{Y}$ & $\mathrm{Y}$ & $\mathrm{Y}$ \\
\hline & Starts & $\begin{array}{l}\text { Nov } \\
2018 \\
\end{array}$ & Dec 2019 & Jan 2019 & Feb 2019 & $\begin{array}{c}\text { Mar } \\
2019 \\
\end{array}$ \\
\hline $\begin{array}{l}\text { Innovation, cooperation and business } \\
\text { performance: Some evidence from In- } \\
\text { donesian small food processing } \\
\text { cluster, Mukhamad Najib, Akira } \\
\text { Kiminami, } 2011\end{array}$ & $\begin{array}{l}\text { Started } \\
\text { research } \\
\text { and finished } \\
\text { in } 2011\end{array}$ & & & & & \\
\hline $\begin{array}{l}\text { Historical outlook of Indonesian } \\
\text { competitiveness: Past and current } \\
\text { performance, Sari Wahyuni, Kwan } \\
\text { Kee } \mathrm{Ng}, 2012\end{array}$ & $\begin{array}{l}\text { Started } \\
\text { research } \\
\text { and finished } \\
\text { in } 2012\end{array}$ & & & & & \\
\hline $\begin{array}{l}\text { The international expansion of } \\
\text { China's small-and medium-sized } \\
\text { business: Status today and future } \\
\text { outlook, Cardoza Guillermo, Fornes } \\
\text { Gaston, } 2013\end{array}$ & $\begin{array}{l}\text { Started } \\
\text { research } \\
\text { and finished } \\
\text { in } 2013\end{array}$ & & & & & \\
\hline $\begin{array}{l}\text { Financing small and medium } \\
\text { Enterprises in Asia and the Pacific, } \\
\text { Masato Abe, Michael Troilo, Orgil } \\
\text { Batsaikhan, } 2015\end{array}$ & $\begin{array}{l}\text { Started } \\
\text { research } \\
\text { and finished } \\
\text { in } 2015\end{array}$ & & & & & \\
\hline B10 Indonesia, Budiman Goh, 2016 & $\begin{array}{l}\text { Started } \\
\text { research } \\
\text { and finished } \\
\text { in } 2016\end{array}$ & & & & & \\
\hline $\begin{array}{l}\text { Socio-cultural environments and } \\
\text { emerging economy entrepreneurship: } \\
\text { Women entrepreneurs in Indonesia, } \\
\text { Grisna Anggadwita, Bachruddin Saleh } \\
\text { Luturlean, Veland Ramadani, Vanessa } \\
\text { Ratten, } 2017\end{array}$ & $\begin{array}{l}\text { Started } \\
\text { research } \\
\text { and finished } \\
\text { in } 2017\end{array}$ & & & & & \\
\hline $\begin{array}{l}\text { The effect of entrepreneurial compe- } \\
\text { tency on product innovation and busi- } \\
\text { ness performance: Empirical cases of } \\
\text { fashion business in central Java, Indo- } \\
\text { nesia, Musthofa, } 2017\end{array}$ & $\begin{array}{l}\text { Started } \\
\text { research } \\
\text { and finished } \\
\text { in } 2017\end{array}$ & & & & & \\
\hline $\begin{array}{l}\text { Factors that determine the perfor- } \\
\text { mance improvement of small and } \\
\text { medium enterprises in Jakarta }\end{array}$ & Nov 2018 & $\begin{array}{l}\text { Plan } \\
\text { research } \\
\text { and } \\
\text { prepare } \\
\text { question } \\
\text { naires }\end{array}$ & $\begin{array}{l}\text { Collect } \\
\text { data }\end{array}$ & $\begin{array}{l}\text { Collect } \\
\text { data }\end{array}$ & $\begin{array}{l}\text { Process } \\
\text { data }\end{array}$ & $\begin{array}{l}\text { End } \\
\text { research } \\
\text { and } \\
\text { submit } \\
\text { report }\end{array}$ \\
\hline
\end{tabular}


Rudy Santosa Sudirga / Factors that Determine the Performance Improvement of Small and Medium Enterprises in Jakarta / JEE, Vol. 7, No. 2, September 2019, pp 73-80

increase and development of small and medium business in Jakarta for the future.

\section{METHOD}

According to (Wijaya, 2013), the basic assumptions that must be met in the analysis of SEM (Structural Equation Modelling) are the number of samples that meet the rules of analysis. According to (Sekaran, 2003) SEM analysis requires a sample of at least 5 times the number of indicator variables used. The Maximum Likelihood Estimation technique requires samples ranging from 100-200 samples. With the number of 30 questionnaire indicators in this research, the number of samples needed for processing using SEM is enough $30 \times 5=150$ samples, but the author will take a minimum number of 200 samples of small and medium business entrepreneurs in Jakarta as research data.

In conducting the required research data collection, the authors conducted primary data collection by distributing questionnaires to several small and medium enterprises in Jakarta, North Jakarta 40 samples, West Jakarta 40 samples, Central Jakarta 40 samples, East Jakarta 40 samples and South Jakarta 40 samples.

In this case the author takes a sample of small and medium enterprises such as food sales business, restaurant business, food stalls, business selling noodles, bakery business, shoe repair business, trading business, building and paint materials business, food catering business, electrical appliance business, sports equipment business, clothing and batik sales business, refill drinking water business, photo copy and advertising creation business, printing business, tire sales business, workshop business, drug store business, bicycle sales business, business tutor- ing course, business courses in baking production, business in English language courses, business in Mandarin language courses, business of selling musical instruments and music courses, business of selling fresh fish, business of selling stationery and office equipment, bookstore businesses, sewing courses, etc., and generally dominated by home business food, business selling noodles, food stalls, bakery businesses, and selling food and cakes.

The sampling technique carried out by the authors is the proportionate stratified random sampling which includes probability sampling or random sampling. According to (Sumarni \& Wahyuni, 2006), proportionate stratified random sampling is a sampling technique that is used when the condition of the population is heterogeneous and structured proportionally. The model has a higher statistical efficiency than the simple random sample generated.

Table 2 Profile of Respondent by Education

\begin{tabular}{lcc}
\hline Education & Total & Percentage (\%) \\
\hline SD & - & - \\
\hline SMP & 12 & 6.00 \\
\hline SMA/SMK & 152 & 76.00 \\
\hline S1 & 31 & 15.50 \\
\hline S2 & 5 & 2.50 \\
\hline S3 & - & - \\
\hline Others & - & - \\
\hline Total & $\mathbf{2 0 0}$ & $\mathbf{1 0 0}$ \\
\hline
\end{tabular}

Source: Based on research result

Table 3 Profile of Respondent Based on Age

\begin{tabular}{ccc}
\hline Age (Year) & Total & Percentage (\%) \\
\hline $10-20$ & - & - \\
\hline $21-30$ & 8 & 4.00 \\
\hline $31-40$ & 63 & 31.50 \\
\hline $41-50$ & 117 & 58.50 \\
\hline $51-60$ & 12 & 6.00 \\
\hline $61-70$ & - & - \\
\hline $71-80$ & - & - \\
\hline Total & $\mathbf{2 0 0}$ & $\mathbf{1 0 0}$ \\
\hline
\end{tabular}

Source: Based on research result 
Rudy Santosa Sudirga / Factors that Determine the Performance Improvement of Small and Medium Enterprises in Jakarta / JEE, Vol. 7, No. 2, September 2019, pp 73-80

Table 4 Profile of Respondent Based on Turnover - Income

\begin{tabular}{lcc}
\hline $\begin{array}{c}\text { Turnover }- \\
\text { Monthly Income }\end{array}$ & Total & Percentage (\%) \\
\hline$<10$ million & - & - \\
\hline $11-30$ million & 4 & 2.00 \\
\hline $31-50$ million & 12 & 6.00 \\
\hline $51-70$ million & 21 & 10.50 \\
\hline $71-90$ million & 41 & 20.50 \\
\hline$>90$ million & 122 & 61.00 \\
\hline Total & 200 & 100 \\
\hline
\end{tabular}

Source: Based on research result

\section{RESEARCH INSTRUMENT}

The research instrument uses a 5-level Likert scale, and the questionnaire results are for processing data with multiple regression analysis, where exogenous or independent variables are business innovation or product innovation (product business innovation), business competency, business capital, community population, and environmental factors, which have influential or effect on the business performance variable of small and medium enterprises, which is an endogenous or dependent variable.

\section{DATA ANALYSIS TECHNIQUE}

According to (Hair, et al., 2010), multiple regression is the right analysis when research involves a dependent variable that is estimated to be related to one or more independent vari- ables. The purpose of multiple regression analysis is to estimate the response changes in the dependent variable to several independent variables. For this causal research, the author processes research data with Structural Equation Modelling IBM SPSS Amos version 23.

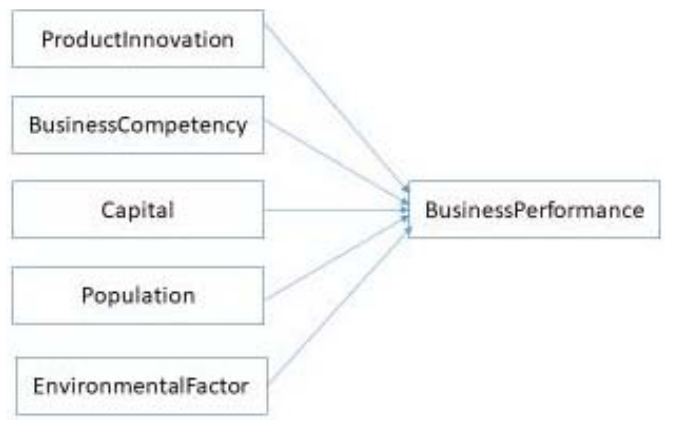

Figure 1: Multiple Regression Source: Based on Wijaya, 2013

\section{RESULTS}

From the results of data processing with Structural Equation Modelling IBM SPSS Amos version 23, the following results are obtained:

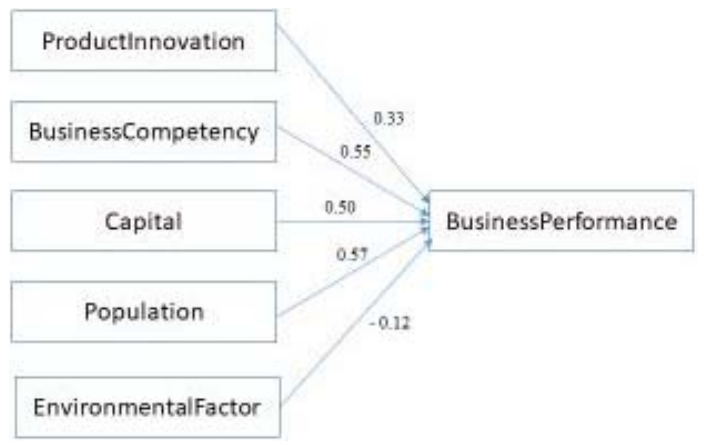

Figure 2: Output Data Analysis Source: SEM processing results

Table 5 Regression Weight

\begin{tabular}{lll|ccccc}
\hline & & & Estimate & S.E. & C.R. & P & Label \\
\hline Business Performance & $<---$ & Product Innovation & 0.496 & 0.114 & 4.352 & $* * *$ & par_1 \\
Business Performance & $<--$ & Business Competency & 1.24 & 0.262 & 4.735 & $* * *$ & par_2 \\
Business Performance & $<---$ & Capital & 1.033 & 0.188 & 5.494 & $* * *$ & par_3 \\
Business Performance & $<---$ & Population & 1.177 & 0.169 & 6.977 & $* * *$ & par_4 \\
Business Performance & $<--$ & Environmental Factor & -0.235 & 0.131 & -1.797 & 0.072 & par_5 \\
\hline
\end{tabular}

Source: SEM processing results 
Rudy Santosa Sudirga / Factors that Determine the Performance Improvement of Small and Medium Enterprises in Jakarta / JEE, Vol. 7, No. 2, September 2019, pp 73-80

Table 6 Standardized Total Effects

\begin{tabular}{l|ccccc}
\hline & $\begin{array}{c}\text { Environmental } \\
\text { Factor }\end{array}$ & Population & Capital & $\begin{array}{c}\text { Business } \\
\text { Competency }\end{array}$ & $\begin{array}{c}\text { Product } \\
\text { Innovation }\end{array}$ \\
\hline Business Performance & -.123 & .568 & .502 & .548 & .331 \\
\hline
\end{tabular}

Source: SEM processing results

The Regression Weights table shows the estimated effect of variables on other variables and other probabilities, as follows:

- Product Innovation Business Variables have a significant effect on Business Performance (probability of $0.000<0.05$, with beta coefficient of 0.496).

- The Business Competency variable has a significant effect on Business Performance (probability of $0.000<0.05$, with beta coefficient of 1.240).

- The Capital Investment variable has a significant effect on Business Performance (a probability of $0.000<0.05$, with a beta coefficient of 1.033).

- Population variables have a significant effect on Business Performance (probability of 0.000 $<0.05$, with beta coefficient of 1.177).

- Environmental Factor variables have no significant effect on Business Performance (probability of $0.072>0.05$, with beta coefficients of -0.235 ).

Standardized total effects show the effect of total (total from direct and indirect) of an independent variable on the dependent variable. In this case the standardized total effects are of the same value as the standardized direct effects, because there is no value from the standardized indirect effects, namely the indirect effect of all of these variables on business performance variable.

- The effect of the total Product Innovation Business variable on Business Performance is 0.331 .
- The effect of the total Business Competency variable on Business Performance is 0.548 .

- The effect of the total Capital Investment variable on Business Performance is 0.502 .

- The effect of the total Population variable on Business Performance is 0.568 .

- The total effect of the Environmental Factor variable on Business Performance is - 0.123.

\section{DISCUSSION}

The results of respondents who answered the questions were dominated by respondents with a high school education background 152 people (76\%), with ages ranging between 41-50 years 117 people $(58.5 \%)$, and having income turnover above 90 million rupiah per month 122 people (61\%), so it can be categorized that the majority of small and medium business entrepreneurs are educated in high school and are still in the productive age range.

Processing data with IBM SPSS Amos version 23 gives the following results:

- Product Innovation Business variables have a significant effect on Business Performance (probability of $0.000<0.05$ ), and have an effect of $0.331=0.33$. Business Competency variable has a significant effect on Business Performance (probability of 0.000 $<0.05$ ), and has an effect of $0.548=0.55$. Product Innovation and business competency were adopted from (Musthofa, 2017), explained that entrepreneurial competencies and product innovation are able to improve 
business performance significantly, while entrepreneurial competence increase product innovation significantly, and also the results of (Najib, M., Kiminami, A., 2011), using the path analytical method, this paper provides evidence that cooperation is significantly related to innovation of small and medium enterprises in food processing industry clusters. Moreover, business performance is a function of innovation and competencies, in which research results show that innovation and competencies significantly affect the business performance of small and medium enterprises.

- Capital Investment variable has a significant effect on Business Performance (probability of $0.000<0.05$ ), and has an effect of 0.502 $=0.50$, on which capital investment also has a significant effect as shown by the results of (Abe, M., Troilo, M., Batsaikhan, O., 2015), financing is a critical constraint for small and medium enterprises for several reasons. Many small and medium enterprises owners do not manage working capital effectively, information asymmetry between banks and small and medium enterprises retards the loan application and approval process, and underdeveloped equity markets deny small and medium enterprises future growth opportunities. Policymakers can ameliorate conditions by serving as facilitators and communicators for small and medium enterprises to get working capital investment. Also the results of (Wahyuni, S., Ng, K.K., 2012), the Indonesian Government has taken steps in several areas to improve financing investment climate to grow small and medium enterprises.

- Population variables have a significant effect on Business Performance (probability of 0.000 $<0.05$ ), and have an effect of $0.568=0.57$, which also mentioned by (Goh, Budiman, 2016), with the consistent growth over the past decade Indonesia's economy of US $\$ 878$ billion is the largest in South Asia and $16^{\text {th }}$ globally just behind Australia, Mexico and South Korea. It is considered as an emerging market and newly industrialized country with its economy mainly driven by a huge population, domestic consumption and investment.

- Environmental Factor variables have no significant effect on Business Performance (probability of $0.072>0.05$ ), and have an effect of $-0.123=-0.12$, which is according to the study conducted by (Guillermo C., Gaston, F., 2013), this paper shows that two main areas are in need of further research: the impact of the business environment on the international expansion of small and medium enterprises, and the need to understand different elements of the process to develop a strong firm. Also the results of (Anggadwita, G., Luturlean, B.S., Ramadani, V., Ratten, V., 2017), a theoretical framework is empirically tested to identify the impact of the socio-culture environment on behaviour and on women entrepreneurial activity through an integrated analysis. It is recommended to conduct the effect of socio-culture environment insights for the future research.

\section{SUGGESTION}

Based on all of the variables that significantly influence the business performance of the small and medium business, the Business Competency variable (has an influence of 0.55 ), the Capital Investment variable (has an influence of 0.50 ), and the Population variable (has an influence of 0.57 ). These three variables have a very large influence on the Business Performance of small and medium businesses, 
Rudy Santosa Sudirga / Factors that Determine the Performance Improvement of Small and Medium Enterprises in Jakarta / JEE, Vol. 7, No. 2, September 2019, pp 73-80

so it can be suggested that to start a small and medium business, must pay attention to the following factors:

- He/She should be competent in the business.

- Do have enough business capital to start/run the business.

- The population of customers who buy and use these products must be a lot.

\section{LIMITATIONS AND FUTURE STUDY}

Limitations of this paper does not look at investor opinion toward Indonesia which perhaps could help in developing small and medium enterprises business policy in Jakarta.

For future research, the authors propose to include competitor factors, and business excellence factors as exogenous variables (independent variables), and if possible to expand and conduct research in a wider area, i.e. Jakarta, Bogor, Tangerang, Bekasi (Jabotabek).

\section{REFERENCES}

Abe, M., Troilo, M., Batsaikhan, O. (2015). Financing small and medium enterprises in Asia and the Pacific, Journal of Entrepreneurship and Public Policy, 4(1), 2-32. Anggadwita, G., Luturlean, B.S., Ramadani, V., Ratten, V. (2017). Socio-cultural environments and emerging economy entrepreneurship: Women entrepreneurs in Indonesia. Journal of Entrepreneurship in Emerging Economies, 9(1), 85-96.

Goh, Budiman. (2016). B10 Indonesia, in John Y. Lo (ed.) Angel Financing in Asia Pacific, 227-239.

Griffin, R.W., Pustay, M.W. (2015). International business, A managerial perspective ( $8^{\text {th }}$ ed.). UK: Pearson Education Limited.
Guillermo C., Gaston, F. (2013). The international expansion of China's small- and medium-sized business: Status today and future outlook. Journal of Chinese Entrepreneurship, 5(3), 252-273.

Hair, Black, Babin, Anderson. (2010). Multivariate data analysis $\left(7^{\text {th }}\right.$ ed.). Upper Saddle River, NJ: Pearson Education, Inc.

Keller, K. L. (2013). Strategic brand management (14 $4^{\text {th }}$ ed.). Upper Saddle River, NJ: Pearson Education, Inc.

Mc.Daniel, C., Gitman, L.J. (2015). The future of business ( $8^{\text {th }}$ ed.). Cincinnati, OH: Thomson South-Western.

Musthofa, (2017). The effect of entrepreneurial competency on product innovation and business performance: empirical cases of fashion business in central java, Indonesia. International Refereed Research Journal, 8(2), 13-21.

Najib, M., Kiminami, A. (2011). Innovation, cooperation and business performance: Some evidence from Indonesian small food processing cluster. Journal of Agribusiness in Developing and Emerging Economies, 1(1), 75-96.

Sekaran, Uma. (2003). Research methods for business - a skill building approach $\left(4^{\text {th }}\right.$ ed.). John Wiley \& Sons, USA

Sumarni, M., Wahyuni, S. (2006). Metodologi penelitian bisnis ( $1^{\text {st }}$ ed.). Yogyakarta: Penerbit ANDI.

Wahyuni, S., Ng, K.K. (2012). Historical outlook of Indonesian competitiveness: past and current performance. Competitiveness Review: An International Business Journal, 22(3), 207-234.

Wijaya, T. (2013), Analisis Structural Equation Modeling Menggunakan AMOS (5 $5^{\text {th }}$ ed.). Yogyakarta: Penerbit Universitas Atma Jaya. 